\title{
THE RECENTLY DISCOVERED SARCOPHAGUS OF PTAHSHEPSES AT SAQQARA
}

\author{
Soleiman, S. \\ Egyptology dept., Faculty of Archaeology, Damietta Univ., Damietta, Egypt. \\ E-mail:saleh_suleiman82@yahoo.com
}

\section{Abstract}

This article ${ }^{(a)}$ deals with a new discovered and unpublished sarcophagus found inside an old kingdom tomb at Saqqara, describing that sarcophagus and its decoration, translating the accompanied texts, commenting and comparing it with the other sarcophagi relating to the relevant period.

Keywords: Ptahshepses, Themi, Manufacture of sarcophagus, Transfer of sarcophagus, wditt-eyes

\section{Introduction}

Ptahshepses' tomb was discovered in 2010 by the mission of the Egyptian Supreme Council of Antiquities (SCA), under my supervision with my colleague A. El-Batal. It is located in the Gisr elMudir site, west of the Step Pyramid at Saqqara $^{(b)}$. This tomb consists of three levels: a top one represents its core, surrounded by an enclosure wall, the second level represents its chapel, which consists of two rock cut courts. The first

an offering room, cased with limestone from Tura and decorated with daily life scenes. The third level represents its burial chamber, which is also decorated. The burial chamber is located east and south of the shaft, which is located north-west of the chapel at the core of the top level of the tomb, fig. (1). It contains an inscribed sarcophagus in the western part, between the shaft and the south wall of this room. is opened and the second is vaulted, and

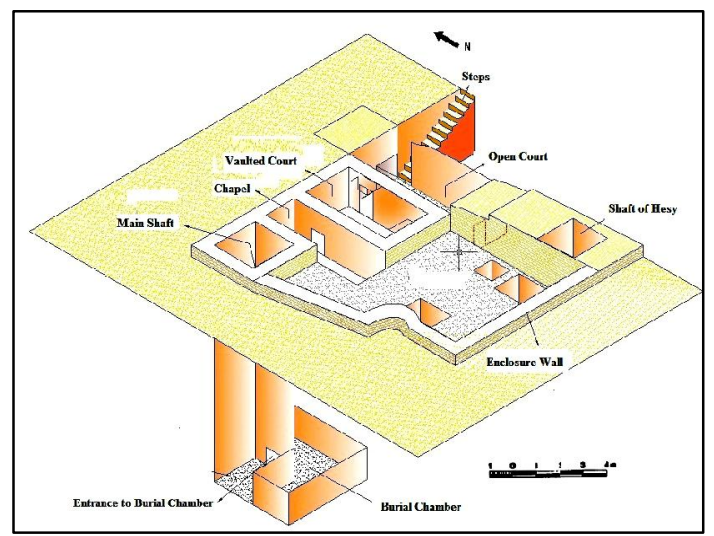

Figure (1) Shows three-dimensional view of the funerary complex of Ptahshepses 


\section{Architectural Feature of Ptahshepses' Sarcophagus}

Ptahshepses' sarcophagus is made of fine white limestone. It is positioned on the west side of the burial chamber in a north-south direction, fig s. $(2-a, b, c)$. It consists of two pieces: a roughly cut convex rectangular lid measuring $287 \times$ $131 \times 53 \mathrm{~cm}$ and a well cut and polished rectangular chest. The external dimensions of the chest are $280 \times 130 \times 111 \mathrm{~cm}$ high and the internal dimensions are $208 \times$ $65 \times 80 \mathrm{~cm}$ deep. The lid has a raised and fattened band and pair of projecting knobs at each of the narrow ends $17 \mathrm{~cm}$. It is formed of one massive, hollowed out block. The thickness of the northern and southern sides of the chest is $36 \mathrm{~cm}$. each and the eastern and western sides are $31 \mathrm{~cm}$. each. The sarcophagus was found empty. It had been robbed from a broken cut in the northern part of the east side of the chest and partly in its lid. It measures $126 \times 30 \mathrm{~cm}$.
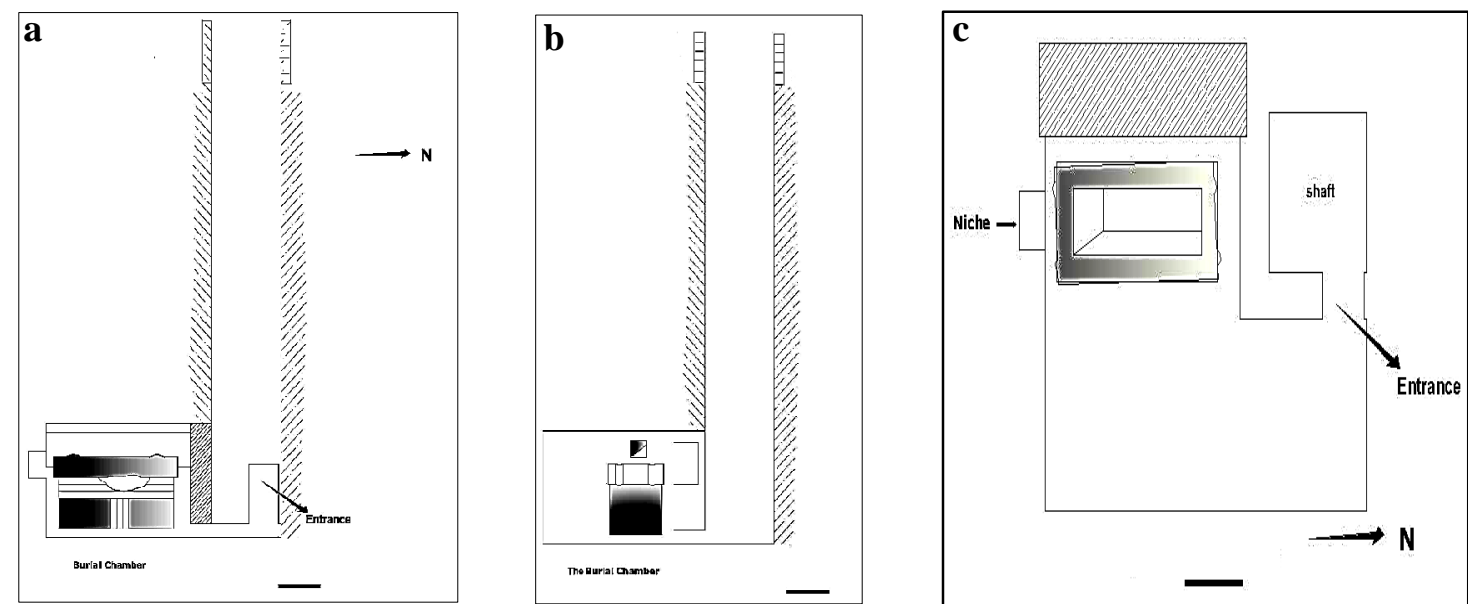

Figure (2) show $\underline{\mathbf{a}}$. \& $\underline{\mathbf{b}}$. section, $\underline{\mathbf{c}}$. plan of the shaft and burial chamber of Ptahshepses

\section{The Decoration of Ptahshepses' Sarcophagus}

\subsection{The outer eastern side}

The northern part of the eastern side of the chest of Ptahshepses' sarcophagus is decorated from outside with two $w \underline{d} 3 t$ eyes, carved in sunk relief, colored black and broken in some parts, fig s. $_{\text {(3-a,b, }}$ d,e). To the south of these eyes, a palace façade is drawn with black ink. There are four lines of hieroglyphs in sunken relief.

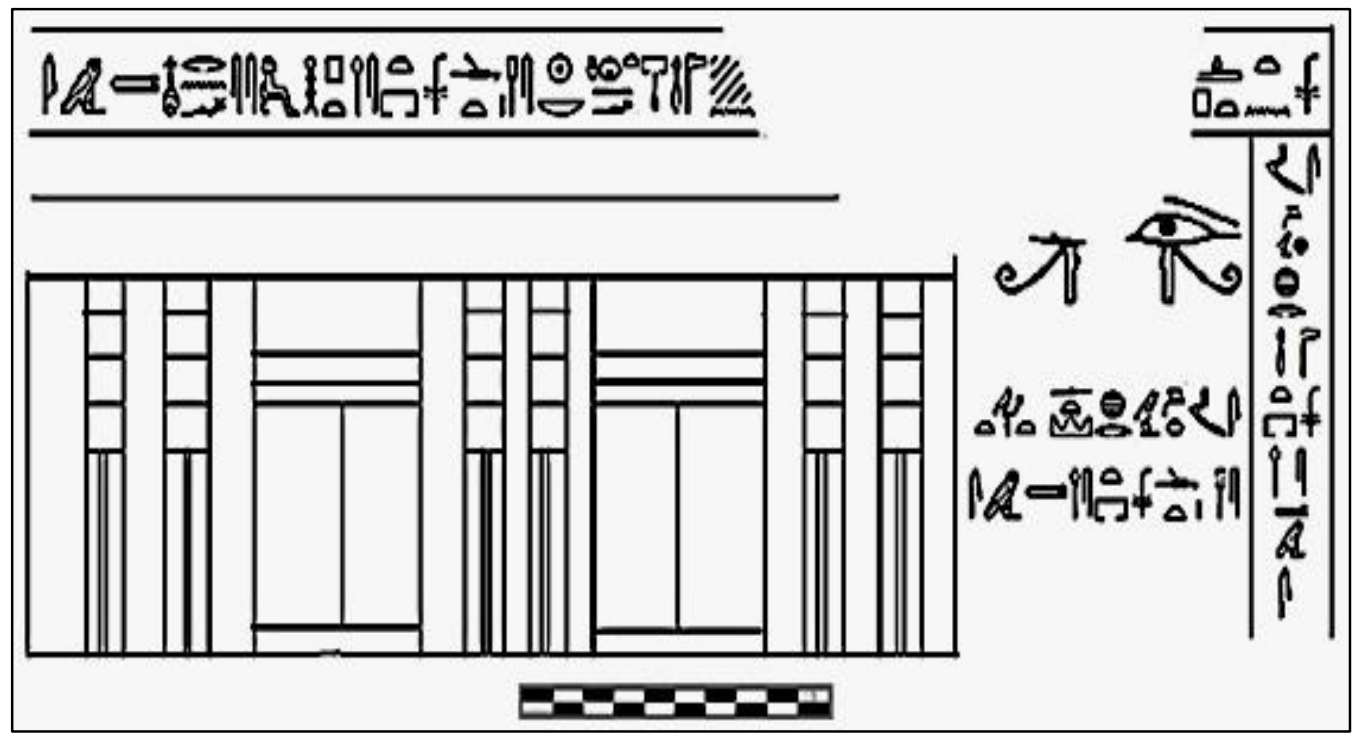

Figure (3-a) Shows the outer eastern side of the sarcophagus 

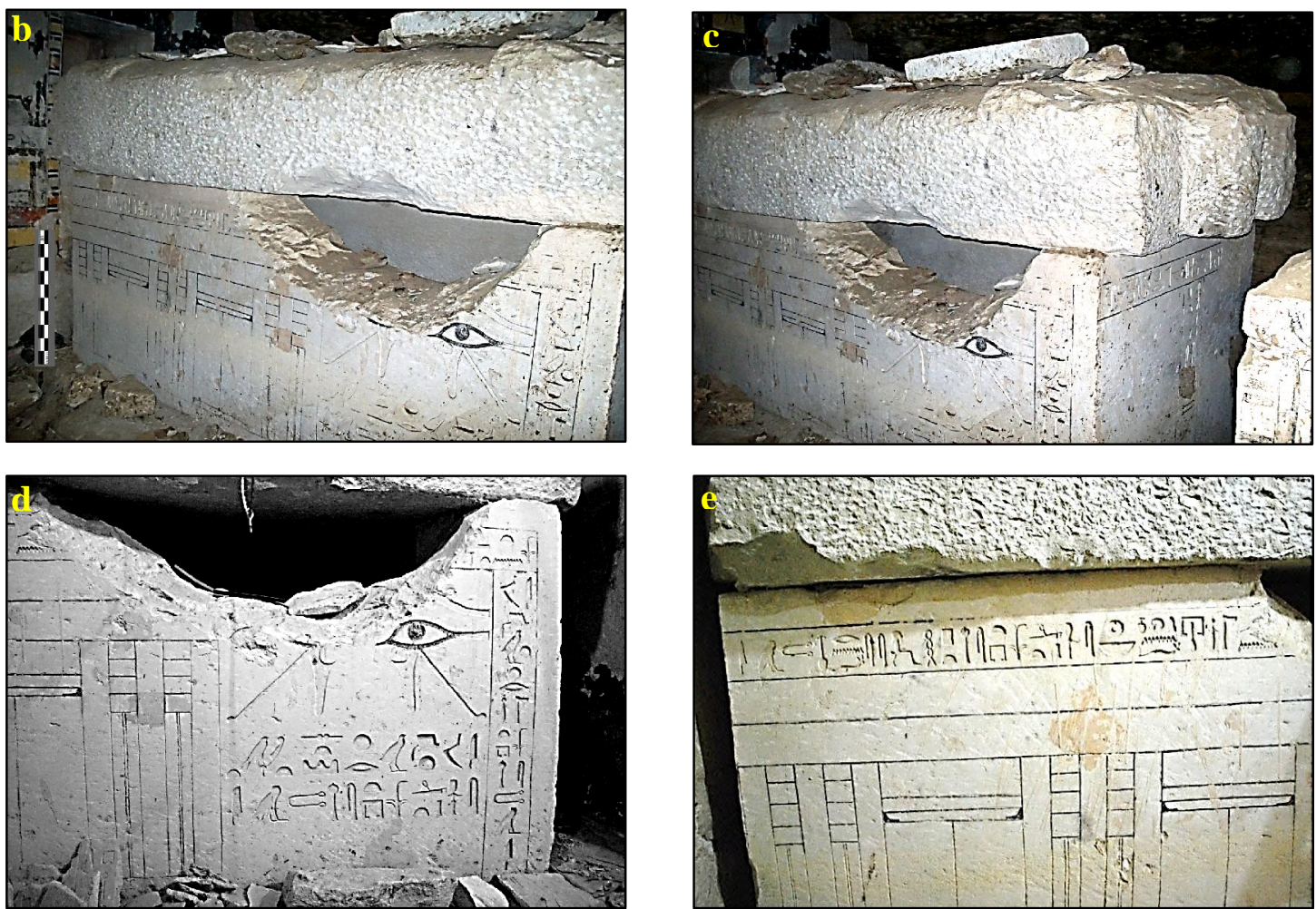

Figure (3) Shows different sides of the sarcophagus $\underline{\mathbf{b}}$. eastern side, $\underline{\mathbf{c}}$. eastern and northern sides, $\underline{\mathbf{d}}$. northern part of the eastern side, $\underline{\mathbf{e}}$. southern part of the eastern side

\subsubsection{The top horizontal line}

The top horizontal line of the outer eastern side of sarcophagus is directed from

right to left, has some blue color, and is broken in one part:

F

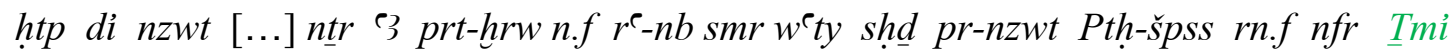

An offering which the king, $[\ldots]$ and the great god, [give that] may an invocation offering come forth for him daily, the sole companion, inspector of the royal domain, Ptahshepses whose good name is Themi/Tjemi.

\subsubsection{The northern vertical line}

In this line, there is one vertical includes one epithet, the main title and text directed from right to left. It the name

\section{$43-898 \neq 0990$

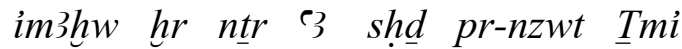

The revered with the great god, inspector of the royal domain, Themi.

\subsubsection{The bottom horizontal lines}

In the bottom horizontal lines of there are two lines under the two $w d \underline{d} t$ the outer eastern side of sarcophagus, eyes, directed from right to left.

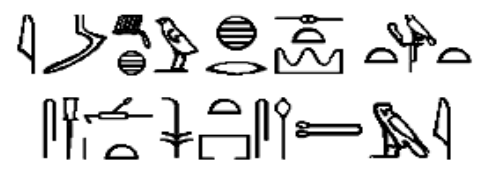

im3hw hr Zmit imntt smr w'ty shd pr-nzwt Tmi

The revered one with goddess Zmit imntt, the sole companion, inspector of the royal domain, Themi. 


\subsection{The outer northern side}

In this side of sarcophagus, there are two lines; one horizontal and one vertical, directed from left to right. This text includes one epithet, two titles and two names. The last part of the horizontal line is damaged, fig. (4-a).

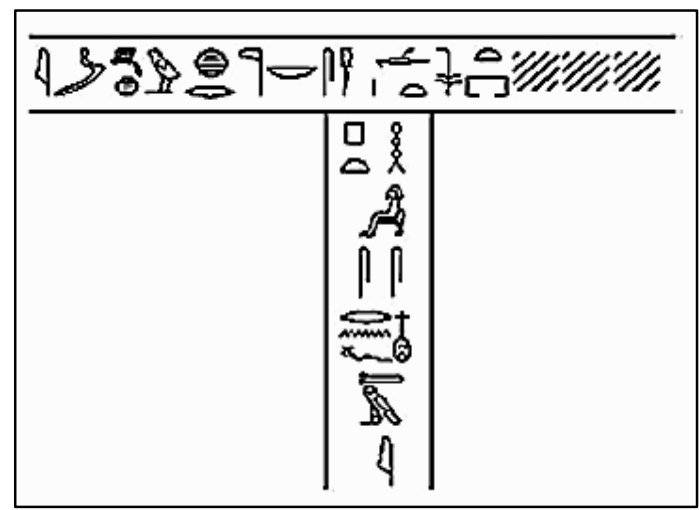

Figure (4-a) Shows the outer northern side of the sarcophagus

\subsubsection{The top horizontal line}

It could be noted that the text in the top horizontal line of sarcophagus is

directed from left to right, still have some blue color

$$
\text { im3hw hr ntr nb smr wrty [shd] pr-nzwt [...] }
$$

The revered one with each god, the sole companion, [Inspector] of the royal domain

$$
\text { [...]. }
$$

\subsubsection{The middle vertical line}

The middle vertical line of the outer northern side of sarcophagus includes

the two names of the deceased, the great one and good name, fig. (4-b)

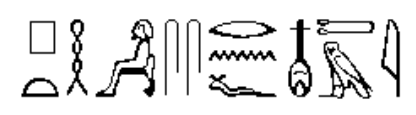

Pth-̌̌spss rn.f nfr Tmi

Ptahshepses whose good name is Themi.

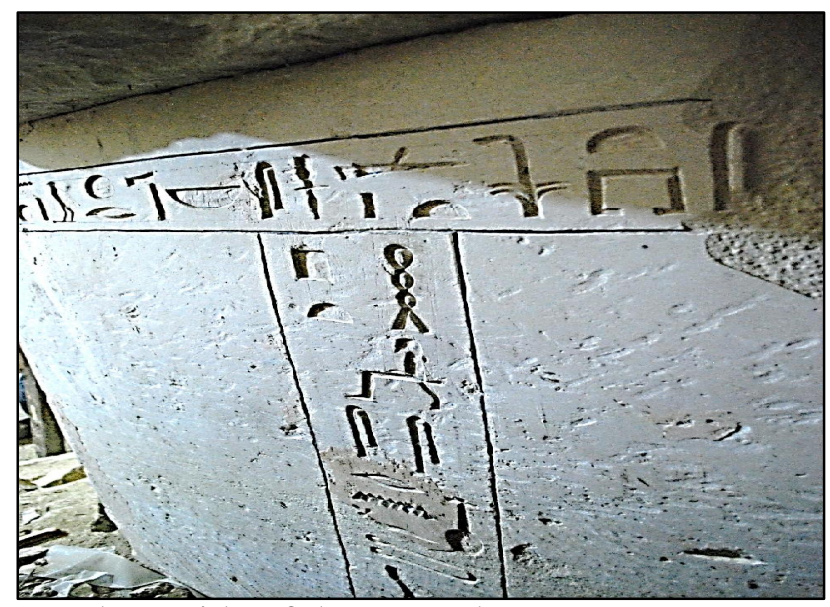

Figure (4-b) Shows the northern side of the sarcophagus

\section{Discussion and Comment}

\subsection{The tomb owner's names}

In our case study; it could be noted that the owner of the tomb has

two names, both of them are mentioned on the sarcophagus. 


\subsubsection{The First Name 응}

This name is written in this way twice on the sarcophagus and many times on the walls of the burial chamber. It is read Pth-špss or Špss-Pth, Ptahshepses or Shepsesptah [1]. Before we discovered the burial chamber and its sarcophagus, we found this name written several times in the chapel in a different form we read it $\breve{S} p s-p w$-Pth, Shepspuptah [1]. Three interpretations are possible as follows: *The tomb owner had both the previous names: Ptahshepses, Shepspuptah. *The sign $\square$, which came at the end of the first name, is a phonetic complement. So the tomb owner's name is Ptahshepses, which was written in the two previous forms. It could be the case that the artists who were engaged in the burial chamber were different from those performed work in the chapel. *Shepspuptah is the correct name of the tomb owner as inscribed on the lintel and on the walls of the chapel, while Ptahshepses, mentioned on the walls of the burial chamber and on the sarcophagus, was probably written by a confused artist since the latter name was more common

\subsubsection{The Second Name $\Rightarrow$ l}

This name is written in this form on the sarcophagus four times and in the same way in all parts of the tomb. It is read $\underline{T} \boldsymbol{T} i$ Themi/Tjemi [1]. It is a simple name. It is mentioned that it is the $r n n f r$ 'the good name', which was

\subsection{The tomb owner's titles on the sarcophagus}

The tomb owner's titles on the sarcophagus are varied and included the next: * im $3 h w$ hr ntr 93 revered one with the great god [3]. * im3hw hr ntr $n b$ revered one with each god. This title is not attested in Jones' study. * im3hw hr Zmit 'Imntt, Jones translated it with 'revered with the western desert/ necropolis' [3]. Actually, Zmit Imntt represents a goddess known since the old kingdom onwards. She is depicted as a lady with the sign of the west on her head [4]. So we prefer to translate the epithet with 'revered one with goddess Zmit 'Imntt. The oldest attestation of this epithet is dated to the reign of Unas in the tombs of Unasankh than the other at that time. It was mentioned in the chapel that Ptahshepses/ Shepspuptah is the $r n$ ' 3 'the great name' on the west wall of the chapel, north of the false door. Most ancient Egyptian names are connected with the names of gods or kings. The name 'Ptahshepses' includes Ptah, one of the most important ancient Egyptian gods and a member of Memphis triad. Ptah appeared in the names of individuals for the first time during the fourth dynasty and became common in the Fifth [2]. Some of the ancient Egyptians used to call their sons names related to the family or the town god. Ptahshepses was living in Memphis, so his family gave him a name incorporating Ptah, the main deity of the triad of Memphis. 'Ptahshepses' is a compound name. It can be Pthšpss, a noun plus an adjective, meaning 'the noble Ptah', or špss-Pth, a nominal sentence with an anticipated adjectival predicate where the name of the god is anticipated for respect and honor. This means 'Ptah is noble' or 'noble is Ptah [1].

given to him by his mother. The owner of the tomb of our study had also two or three names. The ancient Egyptians of the early old kingdom had two and sometimes three names.

$[5,6]$ and Ihy [7]. It continued in the sixth dynasty. This epithet is differ than the other epithet mentioned in other tombs im3hw $m$ Zmit 'Imntt hr 'Inpw, which is translated with 'revered in the western desert/necropolis with Anubis' [3]. * smr $w^{\top} t y$ The sole companion [3]. This honorary title was very important and exclusive till the later fifth dynasty onwards; it was only a ranking title and became more common with all the categories of the officials [8]. * shd $p r$ $n z w t$ Inspector of the royal domain/ house as an actual administrative title held by him [3]. Ptahshepses has about fifty-one titles and epithets attested in 
his tomb's super- and sub-structures [9]. Only five of them are mentioned on the relevant texts on sarcophagus, maybe because of the limited inscribed space on the sarcophagus was the reason for writing a few titles. Ptahshepses mentioned on his sarcophagus three epithets, one honorary title and one Administrative title (sh $\underline{d} p r$ $n z w t)$. Two of his titles (smr $w^{\top} t y$ and shd $p r-n z w t)$ seem to confirm that he had direct relations with king Unas, who granted him this sarcophagus, and kept him close to the person of the king. Each of his first three titles is mentioned once. The fourth title appears three times, and the last title four times. It seems that Ptahshepses was particularly proud of the title shd pr-nzwt and wanted to emphasis it as much as he was able. That it is mentioned more than any other title. So this title is the main and most favorite one for the tomb owner. We have in the old kingdom a few other persons who held this title, such as Khentika/ Ikhekhi and one of his attendants [10], Shedyptah [11], Nyankhnefertem [12], in addition to Ptahshepses and his two sons. It is a comparatively rare title. Its eldest attestation is in the recently discovered tomb of Ptahshepses, which is dated to Unas' reign, but the other previous examples are dated to Pepy I or Pepy II.

\subsection{The architecture of the sarcophagus}

Ptahshepses was buried in a free standing sarcophagus, not in an embedded sarcophagus or a burial pit [13]. It was received as a gift from his Lord Unas. The Kings of the old kingdom often bestowed gifts or rewards on their officials $^{(\mathrm{c})}$. This might be a complete tomb or parts of it such as an entrance (Weni) [14], a false door (Nyan-khsekhmet No. 74/D12 [15] and Weni), a statue (Debehen) [16], an offering table (Weni), a coffin

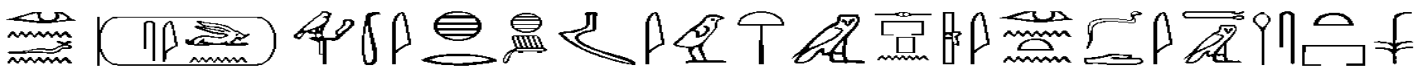

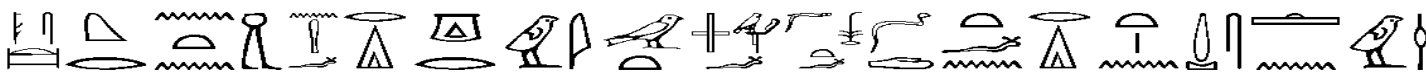

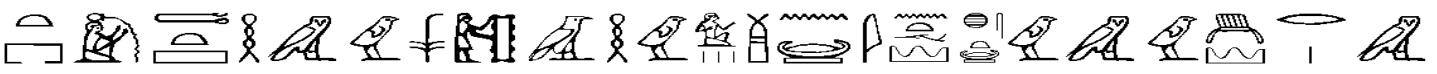

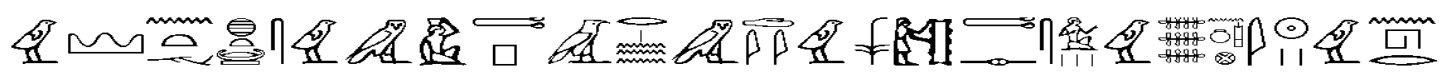

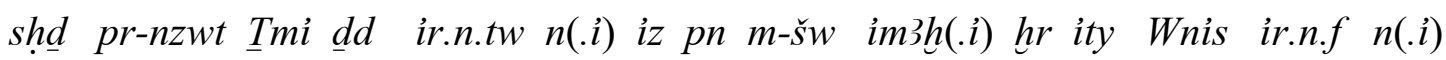
$w \underline{d}-n-s \underline{d} 3 t \quad n$ rdit.f $n \underline{d d}(. i)$ rsyt-mhyt.f imnt-imy-wrt.f iw $g r$ rdi.n hm.f int

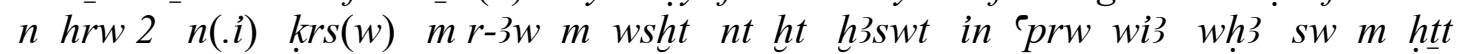
in $z \dot{3} w$ iwnw sts swdy $m$ r-mw 3tp $m$ wsht $n t$ ht ḩ ḩswt

Inspector of the royal domain Themi says "This tomb was made for me because I was honored by the sovereign Unas who made for me a royal command/decree including my request for its south, north, west and east measurements. More than this, his majesty caused that bringing to me a sarcophagus from Turah in wsht-bark of the foreign wood by boat crews (sailors), cutting it in $\underline{h} \underline{t} t$-workshop in two days by the Heliopolis' phyles, dragging and bringing it to the river (or water) edge, and loading it in wsht-bark of the foreign wood". Ptahshepses acquired this sarcophagus from King Unas, who sent the boat-crew on a boat made of the foreign wood to bring it from Turah. The text refers to the steps of making and transporting the sarcophagus: cutting the stone from the Quarry, transporting it to the workshop of'Iwnw, carving the sarcophagus in two days, transporting it to the river edge, and loading it onto the wooden boat. Ptahshepses' text ends without referring to the next stages of 
the sarcophagus. But the text of the vizier of king Djedkare/Isesi named Senedjemib, whose tomb LG 27 / G 2370 located in the western cemetery at Giza, completes the story. He mentions conveying the sarcophagus by water from Turah, reaching the royal necropolis of Khufu, and placing it in its location in the tomb, after five or seven days in transit [18]. Ptahshepses' sarcophagus is rectangular in shape, roughly hewn on the inside, has straight sides, and square corners. This shape appeared from the beginning of the third dynasty onwards $[20,21]$. The old kingdom sarcophagi lids were either quite plain or flat, or slightly convex with a raised, broad band (crosspieces) at the head and foot [22]. Ptahshepses' sarcophagus is in the later style, which appeared from the second dynasty onwards [20]. It may perhaps be considered typical as this is in the form of the hieroglyphic sign $\oslash$ used as a determinative for sarcophagus, burial and related words [23]. This round-topped form was perhaps originally inspired by the tumulus surmounting the primitive grave [22], or in my opinion the primeval mound of the beginning of creation, or an imitation of the lower Egypt sanctuary at Buto Pr$n w$ [21]. It is supposed the living and dead persons have to visit this town. I think this shape of the sarcophagus may express a symbolic visit to this town, or mean that he is buried in this holy place or in the same shape as the ancestors' or the primary kings tombs. Some lids, as does Ptahshepses' sarcophagus, have a pair of projecting knobs, protrusions or U-shaped indentations at each of the narrow ends. These provide handles to facilitate carriage and enabled the use of a rope to lower it into place [21, 22]. This feature is characteristic of the lids of the limestone sarcophagi in the fourth and fifth dynasties [24]. Further evidence, that Ptahshepses' sarcophagus is dated to the fifth dynasty. These projections were intended to be broken off after the funeral. But, perhaps because of the oversight or laziness, they were left in place [21]. Ptahshepses' sarcophagus belongs to the fourth type of the four main types of the old kingdom stone sarc- ophagi, differing in the shape of the lid. It is a rectangular box with a large, illdefined lid, slightly rounded, with rudimentary end bars [25]. Ptahshepses' sarcophagus is placed in the west side of the burial chamber and this is the common position [22]. It is positioned in a northsouth direction, the two long sides being east and west, the two short sides north and south. Again this is the usual way. It is not exactly located under the false door, but about $40 \mathrm{~cm}$ to the west. The best position for the sarcophagus is directly beneath the false door in the offering room of the chapel, to enable the $K a$ and $B a$ to find their way between the burial chamber and the chapel, or perhaps more precisely between the sarcophagus and false door [26]. The direction of Ptahshepses' sarcophagus, north-south with the two eyes on the north of the eastern side, is indicative of the burial position during this period. The head was positioned to the north, feet to the south, the body lying on its left side and facing east [20]. There is no fine sand on the ground of sarcophagus. This sand was placed under the body to preserve it [22]. Ptahshepses' tomb includes one sarcophagus made of limestone as in the case for most officials of this period. The oldest limestone sarcophagus is dated to the middle of the fourth dynasty in Giza (The queen $\mathrm{Kha}^{\mathrm{c}}$ merernebti I, the wife of Chephren, then followed by others [27]. It is not carved from granite, schist, or alabaster as are others. The fine white limestone is called inr had $n f r n^{\circ} n w$. It was generally quarried in the immediate vicinity of where it was required [28]. I think the fine white limestone sarcophagus of Ptahshepses has a deeper symbolic and religious meaning. It was quarried in Turah, located to the east, land of the sunrise and the world of the living. So it is connected with the idea of regeneration, the eternal cycle of life and resurrection. Ptahshepses' sarcophagus has the typical measurements of other old kingdom sarcophagi [27]. We are not sure if there was originally a coffin which decayed, or whether there was never a coffin at all as there are 
no remains. Some persons have two containers one inside the other, the outer one being a sarcophagus made of stone and the inner one a coffin made of wood [21]. There is no granite sarcophagus either, to house the limestone sarcophagus of Ptahshepses, as have been found in some tombs [24]. Ptahshepses tried to protect his mummy from robbery in a number of ways: placing the sarcophagus in a burial chamber with a deep shaft (about $11.5 \mathrm{~m}$ ) filled with rubble and blocked, making a limestone sarcophagus to be stronger than wood, the chest from one block and the lid from another; a huge lid and chest making it difficult for robbers to move or break the lid or the chest; placing the sarcophagus very close to the northern, western and southern walls to make it difficult for robbers to find space to break the sarcophagus from these sides. In spite of all these precautions, the robbers found their way on the east side. They destroyed part of the northern eastern side of the chest and lid, close to the head of the deceased, to take the mummy out. We found the sarcophagus completely empty, robbed of its contents like most of the other old kingdom sarcophagi discovered [26]. Ptahshepses' sarcophagus is placed in a large niche cut into the west of the burial chamber. The niche measures $340 \times 210 \mathrm{~cm}$ from the floor of the chamber and goes all the way up to the ceiling. It has a higher platform about $20 \mathrm{~cm}$. Placing the sarcophagus in a recess is known at least from the second dynasty onwards. The west wall of the niche includes a smaller recess (another niche) $360 \times 110 \times 120 \mathrm{~cm}$ with a sill height above the floor of 110 $\mathrm{cm}$. This recess was used for housing the

\subsection{The decoration of ptahshepse}

Some old kingdom sarcophagi are decorated on the lid, outer and inner sides of the chest [27]. Ptahshepses' sarcophagus is only decorated on the outside like others such as: Kawab [5,29], Fefi [5,30] and Ptahhotep II. The lid of Ptahshepses' sarcophagus is not decorated with any scene, in common with those of Isen [5,31], the prince Ptahshepses [5,32] and Akhethotep I. Unlike other sarcophagi, sarcophagus lid before the sarcophagus was covered and sealed after the burial. Kuraszkiewicz suggests that it must have been more difficult to pull the lid out of a niche that was not accessible from both ends [13]. We have a few examples for these types of two niches together in one burial chamber such as Ptahhotep I, Kagemni, Nedjetempet, Ankhmahor, Neferseshemre, Kairer and others [13]. Ptahshepses' sarcophagus was placed in the burial chamber in the following way: after cutting the shaft and the burial chamber, they were filled with sand, above which the sarcophagus was placed on its head side. By emptying the sand, the sarcophagus gradually descended into the shaft and from it into the burial chamber. The entrance to Ptahshepses' burial cha-mber is located south and east of the shaft, it is wide and high enough to allow maneuvering the sarcophagus through it and into place. Following the positioning of the sarcophagus, the entrance was made smaller by the building of stone walls in the south and the southern part of the east side and leaving a small door in the northern part of the east wall. After the burial, the sarcophagus was closed by moving the lid from its shelf to cover the chest. They were joined together with plaster, then the doorway of the burial chamber was blocked with unshaped stones, and finally the shaft was filled. When we discovered this burial chamber, we found the robbers had broken a hole in the southern wall of the shaft to enter the chamber and the main entrance was still blocked by the ancient masonry.

\section{sarcophagus}

which have the image of the leopard skin on top [22]. This represents continuation of the belief of rebirth the deceased from the animal body, so the corpse was enshrouded in animal skin in the early times [21]. Ptahshepses' lid is not also inscribed with any text, in common with those of Senedjemib/Mehi [5,18], Kapi [5,33] and Waatetkhethor [5,34], and unlike other sarcophagi lids which are 
inscribed with the offering formula, titles and name of the deceased such as Kaiemankh [5,35], Mehu [5,36] and Hetep [5, 37]. Some also have an inscribed appeal to the burial men asking that they close the sarcophagus after the burial and offering rewards for them, as can be seen on the sarcophagi lids of Kaaper, Ankhmahor and Khentika [5,27]. The chest of Ptahshepses' sarcophagus is decorated on the outer eastern side, with drawing and some carving, with six panels, and two false doors, or what is called a palace façade. This element of decoration appeared on the long and narrow sides of the coffins from the second dynasty onwards and on the sarcophagi from the fourth dynasty onwards [27]. This palace façade is found in the houses and tombs, so this implies that the sarcophagus is a house or a palace [22], or a second tomb [25], for the deceased to stay in. It is to help the deceased to leave freely and return easily at any time [20]. Also Ptahshepses' sarcophagus is adorned, on the northern part of the eastern side of the chest, with $w d 3 t$-eyes. These eyes refer to the position of the mummy inside the sarcophagus: the head to the north, and lying on the left side. Through these eyes the deceased can watch the offerings, gaze on the rising sun, and to participate in the diurnal journey of the sun god [20]. Also the $w d 3 t$-eyes represent the eye of Horus, these eyes are to protect the body of the deceased and to drive ills from his heart, making him alive and healthy [38]. Dondani suggested that the $w d 3 t$-eyes are more features of coffins more than the sarcophagi [27]. However, the new excavations provide us with many sarcophagi depicting these eyes. Dondani also suggested that the earliest depiction of these eyes is in the sixth dynasty [27] in the tombs of Kaaper, Ankhmahor, Khentika [14], Inumin and

\subsection{The dating}

Ptahshepses' sarcophagus is most probably dated to the reign of Unas of the fifth dynasty, old kingdom, because of the fourth line on the lintel of the
Mereri in Teti's cemetery. They are dated to Teti's and Pepy I's reigns. The eyes in Ptahshepses, Kaaper, Ankhmahor, Khentika and Mereri are depicted on the outer side of the chest, but in Inumin's sarcophagus, it is depicted on the inner side. Ptahshepses is the only example in Unas' cemetery which has these eyes. The chest of Ptahshepses' sarcophagus is inscribed with one offering formula, five titles and epithets, and two names for the tomb owner on the outer eastern and northern faces. This tradition of writing the offering formula, titles and the names of the deceased on the chest is evident from the fourth dynasty onwards. They were written inside and outside the chest [27]. Ptahshepses' offering formula represents an invocation of daily offerings for the deceased. The earliest attestations of this kind of formula are dated to the fourth dynasty for the royal family members: Khufuankh [5,39], Mersyankh II G 7410+ G 7420 [5,27], Khaefminu G 7430+ G 7440 and Iryenwer [27]. Burying the person inside a sarcophagus/coffin could imply that he has become Osiris. It has been suggested by some Egyptologists that the sarcophagus/coffin represents the box that was made by Seth to get rid of his brother Osiris. When Osiris laid in it, Seth and his followers closed it, and threw in the river [21]. The existence of the $w d 3 t$-eyes on the sarcophagus/coffin supports this idea. As was previously mentioned, these eyes are the eyes of Horus, which were offered to his dead father Osiris. So the sarcophagus and/or coffin are the box of Osiris and the wd $3 t$ eyes are the eyes offered to Osiris. So the deceased inside sarcophagus/coffin has become Osiris. The fact that Osiris was used as an epithet of the deceased, before his name, from the middle part of the reign of Pepy II, late the sixth dynasty [40], also lends credence to this theory.

chapel entrance, which mentions the tomb construction and the bringing of a sarcophagus from Turah by a royal decree from king Unas, and the pair of 
projecting knobs of the lid. However, the decoration of the sarcophagus started in the sixth dynasty because of the $w d \underline{t} t$ eyes. The tomb owner died before fini- shing this sarcophagus because of the black lines of the palace façade on the east side of its box.

\section{Conclusion}

From the above, it could be included the next points 1) The individuals of the old kingdom had two and sometimes three names. 2) The eldest attestation of the administrative title shd pr-nzwt is dated to Unas' reign in this recently discovered tomb of Ptahshepses, but all the other examples are dated to Pepy I or Pepy II. 3) There is a new epithet mentioned on this sarcophagus of Ptahshepses, it is im $3 \mathrm{hw}$ hr ntr $\mathrm{nb}$. It is not recorded in any published tomb in the old kingdom and is not recorded in any study of the epithets and titles of that relevant period. 4) It is better to translate im3hw hr Zmit 'Imntt with 'revered one with goddess Zmit 'Imntt'. It appeared from the reign of Unas onwards. 5) It would appear to be the case that the king, in the old kingdom, was the only person who gave orders to cut stones from the quarries to make sarcophagi and other funerary objects for officials as rewards or gifts. 6) The steps of making and transporting the sarcophagus are cutting the stone from the Quarry, transporting it to the workshop of 'Iwnw, carving the sarcophagus, transporting it to the river edge, loading it onto the wooden boat, conveying the sarcophagus by water from Turah, reaching the necropolis and placing it in its location in the tomb. 7) This round-topped form of the sarcophagus lid was perhaps originally inspired by the tumulus surmounting the primitive grave, or the primeval mound of the beginning of creation, or an imitation of the Lower Egypt sanctuary at Buto Pr-nw. It is supposed the living and dead persons have to visit this town. This shape of the sarcophagus may express a symbolic visit to Buto, or mean that he is buried in this holy place or in the same shape as the ancestors' or the primary kings tombs. 8) Ancient Egyptians tried to protect their mummies from robbery in a number of ways. Most of them did not succeed and the robbers found their way to the mummy. 9) The fine white limestone has a deeper symbolic and religious meaning. It was quarried in Turah, located to the east, land of the sunrise and the world of the living. So it is connected with the idea of regeneration, the eternal cycle of life and resurrection. 10) Ptahshepses' sarcophagus is the only example in Unas' cemetery which has motif of $w \underline{d} 3$ t-eyes. These eyes are actually started to be in use in Sixth Dynasty. 11) Burying the person inside a sarcophagus/coffin could imply that he has become Osiris. This idea was used earlier than using Osiris as an epithet of the deceased, before his name, which is dated to the middle part of the reign of Pepy II.

\section{Endnotes}

(a) I would like to thank my friend the British teacher Dawn Sedgwick, who reviewed and corrected the English of this article.

(b) We as a team of SCA worked in this site over three years 2008-2011 and discovered many stone/mud brick mastabas and rock cut tombs.

(c) The rewards are physical and moral such as promotions; Jewellery; letters written by the king himself; fields and estates; guards and slaves; bread and beer; a new name; the praise, honor, trust and love of the king;

\section{References}

[1] Scheele-Schweitzer, K., (2014). Die personennamen des Alten reiches, alt Ägyptische onomastik unter lexikog- entering the residence and greeting him; eating with the king; joining him in the royal boat; becoming a member in the court and discussing the cases with the king. For these rewards see: Soleiman, S., (2014). The Self Talks and Appeal to the Living in the Old Kingdom Private Tombs at Memphis Necropolis, CulturalAnalyzing Study, PhD Thesis, Archaeology and Culture Department, Faculty of Arts, Helwan University, Cairo, Egypt.

raphischen und sozio-kulturellen Aspekten, Harrassowitz Verlag, Wiesbaden. [2] Van Dijk, J., (2001). Ptah, in: Redford, 
D., (ed.), The Oxford Encyclopedia of Ancient Egypt, Vol. 3, Oxford Univ. Press, Oxford, 74-76.

[3] Jones, D., (2000). An index of ancient Egyptian titles, epithets and phrases of the old kingdom, BAR 866 (2), Archaeopress Publishers of British Archaeological Reports, Oxford.

[4] Leitz, Ch., (2002). Das lexikon der ägyptischen götter und götterbezeichnungen, Band 6, Uitgeverij Peeters en Dept, Oosterse Studies, Leuven.

[5] Porter, B. \& Moss, R., (1974-1981). Topographical bibliography of ancient Egyptian hieroglyphic texts, reliefs and paintings, Vol. III, Memphis, Part I, Abû Rawâsh to Abûsîr, Part II, Saqqâra to Dahshûr, 3 fascs. $2^{\text {nd }}$ ed., Ashmolean Museum, Oxford.

[6] Onderka, P., (2009). The tomb of Unisankh at Saqqara and Chicago, $1^{\text {st }}$ ed., National Museum, Prague.

[7] Kanawati, N. \& Abder-Raziq, M., (2003). The Unis cemetery at Saqqara, Vol. II, The tombs of Iynefert and Ihy (reused by Idut), Aris and Phillips, Oxford.

[8] Strudwick, N., (1985). The administration of Egypt in the old kingdom: The highest titles and their holders. Kegan Paul Int., London .

[9] Soleiman, S. \& El-Batal, A., (2015). The Gisr el-Mudir cemetery at Saqqara, Vol. IV, The tomb of Ptahshepses, Part I, The tomb owner, architecture and dating of the tomb, Horof, Cairo.

[10] James, T. \& Apted, M., (1953). The mastaba of Khentika called Ikhekhi, Egypt Exploration Society, London.

[11] Fischer, H., (1996). Varia nova, The Metropolitan Museum of Art, NY.

[12] Mysliwiec, K. \& Kuraskiewicz, K., (2010). Saqqara IV, the funerary complex of Nyankhnefertem, Wydawnictwo Neriton, Warszawa.

[13] Kuraszkiewicz, K., (2013). Saqqara $V$, old kingdom structures between the step pyramid complex and the dry moat, Part I, Architecture and devel- opment of the necropolis, Wydawnictwo Neriton, Warszawa.

[14] Strudwick, N., (2005). Texts from the pyramid age, Society of Biblical Literature, Leiden.

[15] Borchardt, L., (1937). Denkmäler des alten reiches im museum von Kairo, $N r$. 1295-1808, Teil I, text und tafeln zu Nr. 1295-1541, Reichsdruckerei Berlin, Berlin.

[16] Hassan, S., (1943). Excavations at Gîza 1932-1933, Vol. IV, Government Press, Bulâq, Cairo.

[17] Mohr, H., (1943). The mastaba of Hetep-her-akhti. study on an Egyptian tomb chapel in the museum of antiquities, Ex Oriente Lux. E. J. Brill, Leiden.

[18] Brovarski, E., (2000). The Senedjemib complex, Part I, The mastabas of Senedjemib Inti ( $G$ 2370), Khnumenti $(G$ 2374) and Senedjemib Mehi (G 2378), Museum of Fine Arts, Boston.

[19] Kaplony, P., (1976). Studien zum grab des Methethi, Monographien der AbeggStiftung Bern.

[20] Lapp, G., \& Niwinski, N., (2001). Coffins, sarcophagi and cartonnages, in: Redford, D., (ed.), The Oxford Encyclopedia of Ancient Egypt, Vol. 1, Oxford Univ. Press, Oxford, pp: 279-287.

[21] Ikram, S. \& Dodson, A., (1998). The mummy in ancient Egypt, equipping the dead for eternity. The American Univ. in Cairo Press, Cairo.

[22] Hassan, S., (1944). Excavations at Gîza 1933-1934, Vol. V, Government Press, Bulâq, Cairo.

[23] Erman, A. \& Grapow, H., (1971). Wörterbuch der Ägyptischen sprache im auftrage der deutschen akademien, Band I, V, Akademie-Verlag, Berlin.

[24] Jánosi, P., (2011). Some remarks on certain sarcophagi of the fifth dynasty, in: Callender, V., Bareš, L., Bárta, M., Jamák, J. \& Krejči, J. (eds.), Times, signs and pyramids, studies in honour of Miroslav Verner on the occasion of his seventieth birthday, Faculty of 
Arts Charles Univ., Prague, pp: 205215.

[25] Brovarski, E., (1984). Sarkophag, in: Helck, W. \& Otto, E., (eds.), Lexikon der Ägyptologie, Band V, Otto Harrassowitz, Wiesbaden, pp: 471-485.

[26] Kanawati, N., (2010). Decorated burial chambers of the old kingdom, The American Univ. in Cairo Press, Cairo.

[27] Roveri, D., (1969). I sarcofagi egizi dalle origini alla fine dell'Antico Regno, Universtà di Roma, Rome.

[28] Lucas, A. \& Harris, J., (1962). Ancient Egyptian materials, $4^{\text {th }}$ ed., London Edward Arnold \& Co., London.

[29] Simpson, W., (1978). The mastabas of Kawab, Khafkhufu I and II, G 7110-20, 7130-40, and 7150 and subsidiary mastabas of street $G 7100$, Museum of Fine Arts, Boston.

[30] Hassan, S., (1932). Excavations at Gîza 1929-1930, Vol. I. The Univ. Press, Oxford.

[31] Simpson, W., (1980). Mastabas of the western cemetery, Part I, Sekhemka, Tjetu I, Iasen, Penmeru, Hagy, Nefertjentet and Herunefer, Djaty, Tjetu II and Nemesti, Museum of Fine Arts, Boston.

[32] Brunton, G., (1947). The burial of prince Ptah-shepses at Saqqara, ASAE, Vol. 47, pp: 125-137.

[33] Roth, A., (1995). A cemetery of palace attendants, including G 2084-2099, $G 2230+2231$, and $G 2240$, Museum of Fine Arts, Boston
[34] Kanawati, N. \& Aber-Raziq, M., (2008). The tomb of Waatetkhethor, Mereruka and his family, Part II, Aris and Phillips, Oxford.

[35] Junker, H., (1943). Grabungen auf dem Friendhof des Alten Reiches bei den Pyramiden von Gîza, Band VI, Die Mastabas der Nfr (Nefer), Kdfy (Kedfy), K3hif (Kahjef) und die westlich anschliessenden Gräbanlagen, HölderPichler-Tempsky A. G., Wien.

[36] Altenmüller, H., (1998). Die wanddarstellungen im grab des Mehu in Saqqara, Philipp von Zabern, Mainz.

[37] Hassan, S., (1975). Excavations at Saqqara 1937-1938, Vol. III, Mastabas of princess Hemet-Re and others, General Organization for Government Printing Offices, Cairo.

[38] Bennett, J., (1967). The symbolism of the mummy case, JEA, Vol. 53, pp: 165-166.

[39] Borchardt, L., (1964). Denkmäler des Alten Reiches im Museum von $\mathrm{Ka}$ iro, Nr. 1295-1808, Teil II, Text und Tafeln zu Nr. 1542-1808. Organisme Général des Imprimeries Gouvernementales, Cairo.

[40] Brovarski, E., (2005). The late old kingdom at south Saqqara, in: Pantalacci, L. \& El-Naggar, Ch., (eds.), Des Néferkarê aux Montouhotep. Tra-vaux archéologiques sur la fin de la $V I^{e}$ dynastie et la première Période Intermédiaire. Actes du Colloque CNRSUniversité Lumière-Lyon 2, Maison de l'Orient, Lyon, pp: 31-63. 